\title{
Serum Magnesium Level in the Salt-losing Type of Congenital Adrenal Hyperplasia
}

\author{
AKIO KOBAYASHI ${ }^{\star}$ and YOSHIO IGARASHI \\ From the Department of Pediatrics, University of Toky'o, Japan
}

Evidence has accumulated that aldosterone plays an important part in the regulation of magnesium metabolism in experimental animals. There is, however, little information concerning the effect of aldosterone on the metabolism of magnesium in man. Mader and Iseri (1955) and Milne, Muehrcke, and Aird (1957) reported a single case of primary aldosteronism, with tetany and paralysis, in which low serum levels of magnesium and potassium were observed. Harrop et al. (1933) and Zwemer and Sullivan (1934) described high serum levels of magnesium in animals with adrenal insufficiency. Investigations have been made into the effects of mineralocorticoids upon the metabolism of magnesium and other electrolytes using adrenalectomized animals (Conway and Hingerty, 1946; Hingerty, 1957; DaVanzo, Crossfield, and Swingle, 1958; Weil and State, 1958). It has been generally agreed that serum potassium and magnesium are conspicuously raised, with parallelism in mineralocorticoid deficiency, and that mineralocorticoids increase the renal excretion of magnesium as well as of potassium.

In the salt-losing type of congenital adrenal hyperplasia $(\mathrm{CAH})$ which is commonly characterized by the defect of 21-hydroxylation in the biosynthesis of cortisol and aldosterone in the adrenal cortex, it is assumed that serum potassium and magnesium levels are raised. However, there have been no reports on magnesium metabolism in $\mathrm{CAH}$. Accordingly, this investigation reports the serum magnesium level and its relation to other electrolytes in two infants with the salt-losing type of $\mathrm{CAH}$, who were treated with mineralo- and glucocorticoids plus salt supplement.

\section{Case Reports}

Two infants with the salt-losing type of CAH, who

Received July 3, 1967.

^Address : Department of Pediatrics, University of Tokyo, Hongo 7-3-1, Bunkyo-ku, Tokyo, Japan. were 15 days and $5 \frac{1}{2}$ months old at the start of the investigation, were studied for 10 days and 7 months, respectively.

Case 1. An 11-day-old female infant, born after a normal pregnancy and delivery with a birthweight of 2900 g. and a non-contributory family history, was admitted because of abnormal genitalia and poor weight gain. Physical examination revealed mild dehydration and a common urogenital sinus, with enlarged clitoris. Her weight was $2700 \mathrm{~g}$. and her length $50 \cdot 0 \mathrm{~cm}$. $\mathrm{Hb}$ 19.0 g. $/ 100 \mathrm{ml}$; ; white blood cells $17,800 /$ c.mm., with normal differential count. Urinalysis revealed no abnormalities. Serum $\mathrm{Na}, \mathrm{K}, \mathrm{Cl}$, and $\mathrm{CO}_{2}$ content were $120,6 \cdot 4,94$, and $12.0 \mathrm{mEq} / 1$, respectively. Total protein, total cholesterol, urea N, and GOT in the serum, normal. A buccal smear for sex chromatin was positive. Urinary excretions of 17-ketogenic steroids (17-KGS) measured by a modification of the method of Few (1961), 17-ketosteroids (17-KS) ty a modification of the method of Drekter et al. (1952), and pregnanetriol by the method of Bongiovanni and Eberlein (1958) were as follows (figures in parentheses indicate values after the cortisol treatment): 11-deoxy-17-KGS $3 \cdot 75 \mathrm{mg}$. $/ 24 \mathrm{hr}$. (1.3); 11-oxy-17-KGS $2 \cdot 94 \mathrm{mg}$. $/ 24 \mathrm{hr}$. (1.54); 11-deoxy- to 11 -oxy-17-KGS ratio $1 \cdot 21(0 \cdot 85)$; 17-KS $1.03 \mathrm{mg} . / 24 \mathrm{hr}$. (0.94); and pregnanetriol 1.41 $\mathrm{mg} . / 24 \mathrm{hr} .(0 \cdot 53)$. The clinical course is shown in Fig. 1 .

Case 2. A 1-month-old male infant, born after a normal pregnancy and delivery with a birthweight of 3700 g., was admitted with complaints of poor drinking and prolonged jaundice. His mother had one previous pregnancy resulting in a full-term infant, who died suddenly on the 7th day of life. On admission, physical examination revealed a slightly jaundiced, pigmented, and malnourished infant with body weight of $3090 \mathrm{~g}$. and body length of $54.0 \mathrm{~cm}$. External genitalia were slightly pigmented and both testes were already descended, but no penile hypertrophy was observed. $\mathrm{Hb}$ $18.5 \mathrm{~g} .100 \mathrm{ml}$.; white blood cells $16,150 /$ c.mm., with normal differential count. Urinalysis revealed slight proteinuria $(10 \mathrm{mg} / 100 \mathrm{ml}$.$) . Serum \mathrm{Na}, \mathrm{K}, \mathrm{Cl}$, and $\mathrm{CO}_{2}$ content were $124,8 \cdot 7,92$, and $15 \cdot 8 \mathrm{mEq} / \mathrm{l}$, respectively. Total protein and total cholesterol in the 


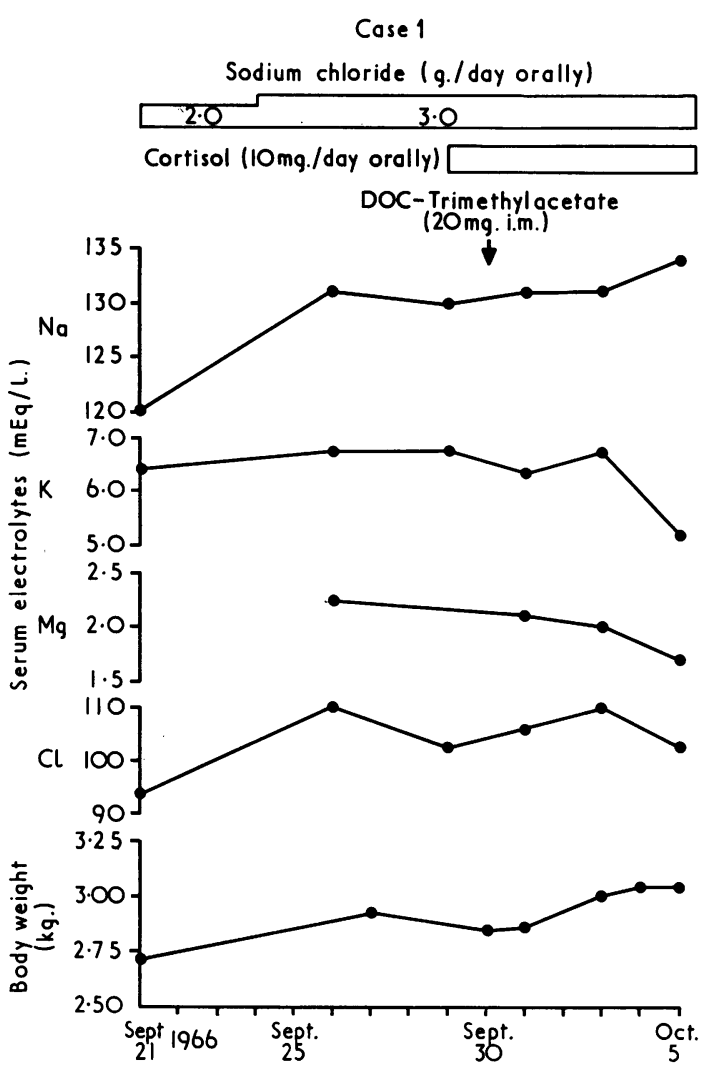

FIG. 1.-Clinical course of Case 1.

serum were normal. Urinary excretions of 17-KGS, 17-KS, and pregnanetriol measured by the same methods as in Case 1, and 17-hydroxycorticosteroids (17-OHCS) measured by the method of Glenn and Nelson (1953) were as follows (figures in parentheses indicate values after the treatment with cortisone and cortisol): 11deoxy-17-KGS $5 \cdot 30 \mathrm{mg}$. $/ 24 \mathrm{hr}$. (0.23); 11-oxy-17-KGS $3.65 \mathrm{mg} . / 24 \mathrm{hr}$. $(0.51)$; 11-deoxy- to 11 -oxy-17-KGS ratio $1.45(0.45) ; 17-\mathrm{KS} 1.29 \mathrm{mg} . / 24 \mathrm{hr}$. $(0 \cdot 17)$; pregnanetriol $4.88 \mathrm{mg} . / 24 \mathrm{hr}$. $(0.02)$; and $17-\mathrm{OHCS}$ $0.7 \mathrm{mg}$. $/ 24 \mathrm{hr}$. $(0 \cdot 2)$. The patient was discharged with incomplete recovery, and was followed at the out-patient clinic (Fig. 2).

Serial determinations of urinary steroids showed that the high excretions of 11-deoxy- and 11-oxy-17-KGS, 17-KS, and pregnanetriol were suppressed by the administration of the cortisol therapy in both cases, resulting in a lowering of the 11-deoxy- to 11-oxy-17-KGS ratio. The diagnosis of the salt-losing type of CAH (21-hydroxylase deficiency) was therefore established.

\section{Methods}

Five serial blood samples were obtained by venous puncture from Case 1, and 16 samples from Case 2, in order to determine serum concentrations of electrolytes. Serum $\mathrm{Na}$ and $\mathrm{K}$ were determined by a flame photometric method and serum $\mathrm{Cl}$ by the method of Schales and Schales (1941). Serum magnesium concentrations were determined by a modification of the method of Schachter (1961) with Multiplier Fluorescence Meter Model 540 (Photovolt Corporation) using B Hg-1 Filter (wave length, $365 \mathrm{~m} \mu$ ) for the primary filter, and B 520 Filter (wave band, 480-580 $\mathrm{m} \mu$ ) for the secondary one. The fluorometric technique used in this study has been described elsewhere (Kobayashi and Shiraki, 1967). Mean recovery by this method was $96 \cdot 8 \%$, with a range of $96 \cdot 2$ to $98 \cdot 0 \%$.

For 16 healthy newborns from 11 to 30 days of age, the mean values of the serum magnesium were 1.68 $\mathrm{mEq} / \mathrm{l}$. (SD $0 \cdot 16$ ), with a range of 1.42 to $1.96 \mathrm{mEq} / 1$, and for 24 healthy infants from 2 months to 1 year, mean values were $2 \cdot 26 \mathrm{mEq} / \mathrm{l}$. (SD $0 \cdot 15$ ), with a range of 1.95 to $2.52 \mathrm{mEq} / 1$. (Kobayashi, 1967).

\section{TABLE}

Serial Determination of Serum Electrolytes ( $m E q / l$. in $\mathrm{CAH}$

\begin{tabular}{|c|c|c|c|c|c|}
\hline Date & $\mathrm{Na}$ & $\mathbf{K}$ & $\mathbf{M g}$ & $\mathrm{Cl}$ & $\begin{array}{l}\mathrm{Na} / \mathrm{K} \\
\text { Ratio }\end{array}$ \\
\hline 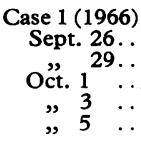 & $\begin{array}{l}131 \\
130 \\
131 \\
131 \\
134\end{array}$ & $\begin{array}{l}6 \cdot 7 \\
6 \cdot 7 \\
6 \cdot 3 \\
6 \cdot 7 \\
5 \cdot 2\end{array}$ & $\begin{array}{l}2 \cdot 24 \\
2 \cdot 08 \\
2 \cdot 00 \\
1 \cdot 72\end{array}$ & $\begin{array}{l}110 \\
102 \\
106 \\
110 \\
103\end{array}$ & $\begin{array}{l}20 \\
20 \\
21 \\
20 \\
26\end{array}$ \\
\hline 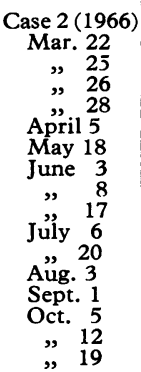 & $\begin{array}{l}136 \\
130 \\
130 \\
134 \\
132 \\
140 \\
136 \\
134 \\
136 \\
134 \\
137 \\
137 \\
140 \\
137 \\
130 \\
137\end{array}$ & $\begin{array}{l}\overline{4} \cdot 9 \\
5 \cdot 2 \\
4 \cdot 7 \\
4 \cdot 9 \\
4 \cdot 4 \\
5 \cdot 1 \\
4 \cdot 4 \\
4 \cdot 0 \\
4 \cdot 2 \\
3 \cdot 7 \\
4 \cdot 2 \\
4 \cdot 6 \\
4 \cdot 0 \\
4 \cdot 4 \\
4 \cdot 3\end{array}$ & $\begin{array}{l}2 \cdot 25 \\
2 \cdot 31 \\
2 \cdot 74 \\
2 \cdot 41 \\
2 \cdot 21 \\
1 \cdot 94 \\
2 \cdot 03 \\
2 \cdot 23 \\
2 \cdot 18 \\
2 \cdot 09 \\
2 \cdot 25 \\
1 \cdot 89 \\
1 \cdot 94 \\
2 \cdot 10 \\
2 \cdot 27 \\
2 \cdot 27\end{array}$ & $\begin{array}{l}102 \\
100 \\
101 \\
106 \\
104 \\
108 \\
106 \\
108 \\
104 \\
107 \\
106 \\
102 \\
107 \\
105 \\
101 \\
100\end{array}$ & $\begin{array}{l}27 \\
25 \\
29 \\
27 \\
32 \\
27 \\
30 \\
34 \\
32 \\
37 \\
32 \\
30 \\
34 \\
30 \\
32\end{array}$ \\
\hline
\end{tabular}

\section{Results}

Serial determinations of serum magnesium and other electrolytes (Table). In the untreated patient (Case 1), who had been given sodium chloride alone 5 days previously, initial serum levels of magnesium and potassium were high whereas serum sodium level was low. After the administration of cortisol, $10 \mathrm{mg}$. daily, and single intramuscular injection of DOC-trimethylacetate, $20 \mathrm{mg}$., the serum magnesium level was reduced to normal as the serum sodium level increased. The serum potassium level, on the other hand, dropped abruptly to normal on the 5th day of treatment with mineralocorticoid. 
Cose 2

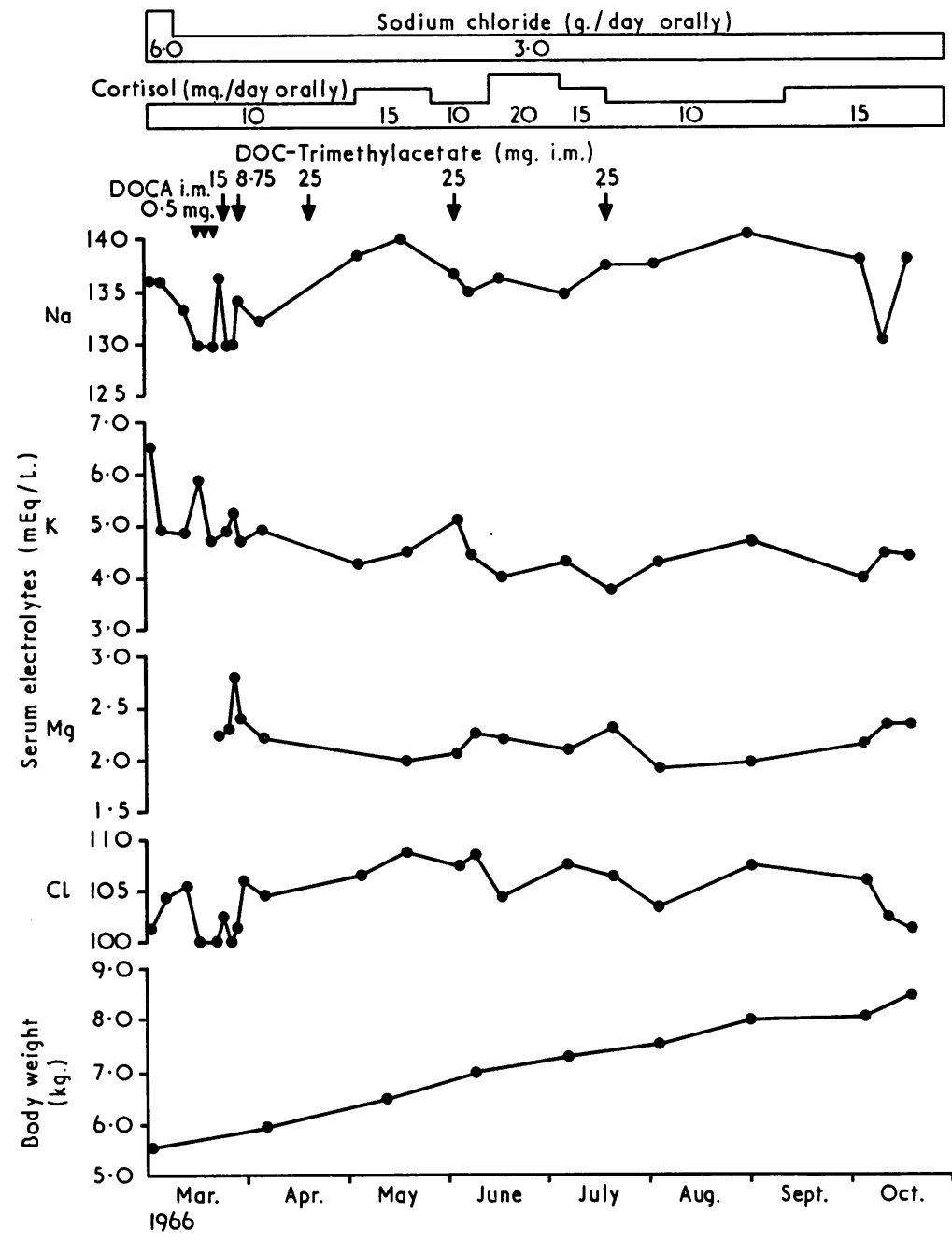

Fig. 2.-Clinical course of Case 2.

In the inadequately treated patient (Case 2), who had been treated as congenital adrenal hyperplasia for about 4 months but was poorly controlled with small amounts of DOCA pellets $(33 \mathrm{mg}$.) given 63 days before the start of the study and the oral administration of cortisol, $10 \mathrm{mg}$. daily, and various amount of salt supplement, serum levels of $\mathrm{Na}, \mathrm{K}$, and $\mathrm{Mg}$ ranged from 130 to $140 \mathrm{mEq} / \mathrm{l}, 3.7$ to $5.2 \mathrm{mEq} / \mathrm{l}$., and 1.89 to $2.74 \mathrm{mEq} / 1$., respectively.

Relationship of serum magnesium to other electrolytes (Fig. 3, 4, and 5). In Case 1, serum magnesium levels were directly proportional to serum potassium, and inversely proportional to serum sodium and $\mathrm{Na} / \mathrm{K}$ ratios.
In Case 2, serum magnesium was inversely correlated with serum sodium $(\mathrm{r}=0.70, \mathrm{p}<$ $0 \cdot 01$ ). Serum magnesium, on the other hand, showed no significant relation to serum potassium or $\mathrm{Na} / \mathrm{K}$ ratio. There was, however, a direct correlation between serum magnesium and potassium $(\mathbf{r}=0.80 ; \mathrm{p}<0.05)$, and an inverse correlation between serum magnesium and $\mathrm{Na} / \mathrm{K}$ ratio $(\mathrm{r}=$ $-0.88 ; \mathrm{p}<0.05)$ in the hyponatraemic condition (serum sodium level was lower than $135 \mathrm{mEq} / \mathrm{l}$.).

\section{Discussion}

Magnesium metabolism is complex compared with other electrolytes, and the precise mechanism 


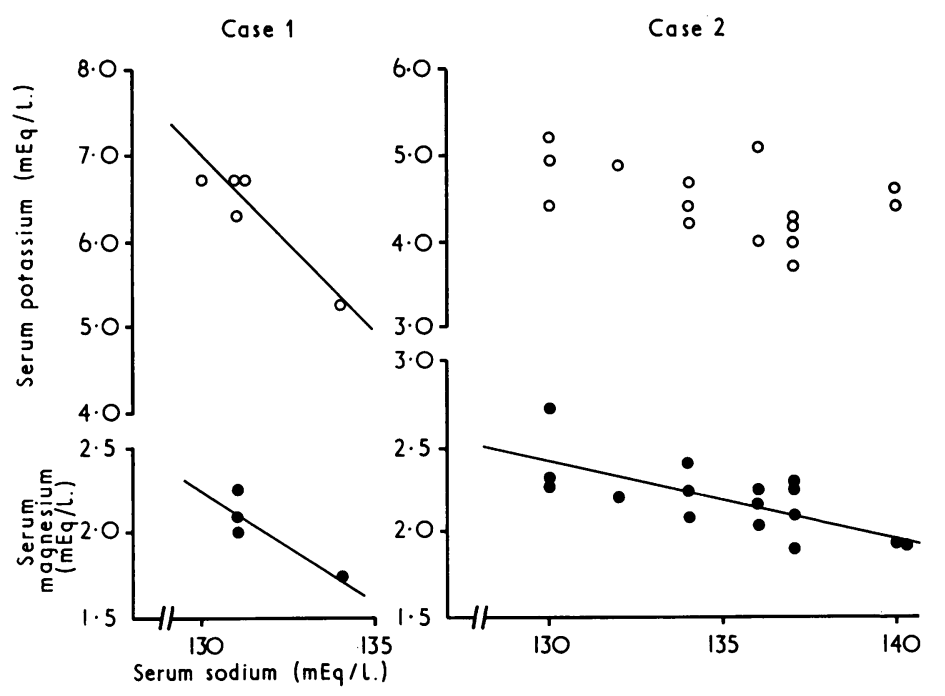

FIG. 3.-Relation of serum magnesium (๑) and potassium (O) to serum sodium levels.

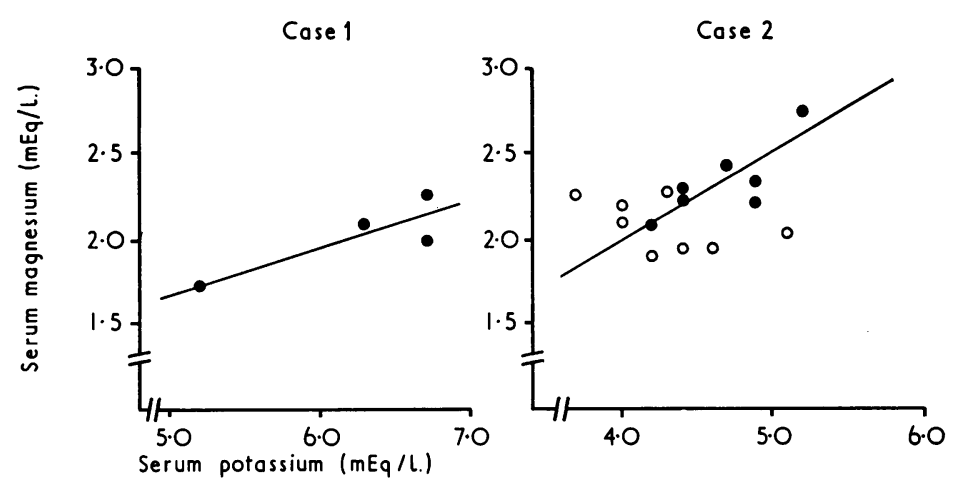

FIG. 4.-Relation of serum levels of magnesium and potassium. Solid circles (๑) indicate values in the hyponatraemic condition, and open circles $(\mathrm{O})$ in the normonatraemic condition.

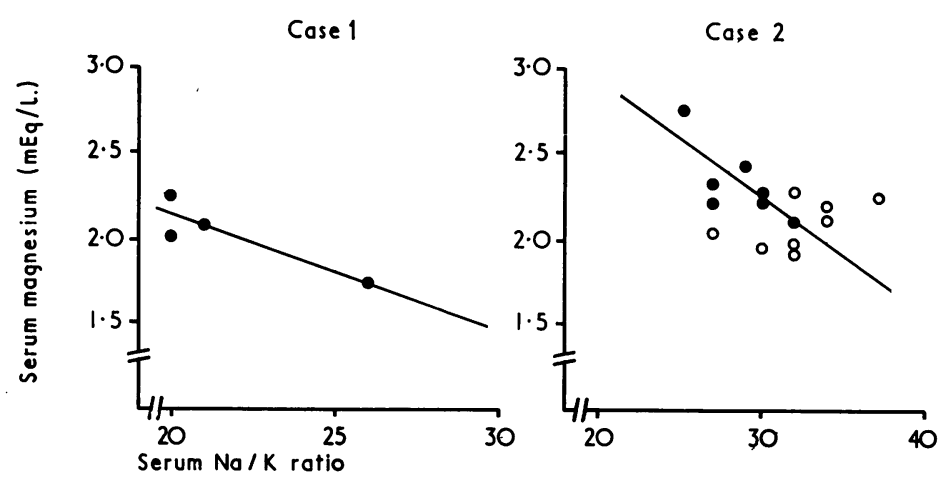

FIG. 5.-Relation of serum magnesium levels to Na/K ratios. Symbols as in Fig. 4. 
of the renal excretion of this ion has not been determined (Hills et al., 1955; Womersley, 1956; Jabir, Roberts, and Womersley, 1957; Chesley and Tepper, 1958; Ginn et al., 1959; Barker, Elkinton, and Clark, 1959; Hills et al., 1959). In recent years, therefore, attention has been directed to the effects of hormones such as aldosterone, parathormone, vasopressin, and so on, which play an important role in the renal excretion of magnesium.

Harrop et al. (1933) and Zwemer and Sullivan (1934) reported high serum levels of magnesium in adrenalectomized rats. Thereafter, it was confirmed by Conway and Hingerty (1946), Hingerty (1957), and Weil and State (1958). Mader and Iseri (1955), Milne et al. (1957), and Horton and Biglieri (1962), on the other hand, observed very low levels of serum magnesium and a concomitant increase in the urinary excretion of magnesium in primary aldosteronism. It has been fairly well established that aldosterone increases the renal excretion of magnesium.

In our patients with congenital adrenal hyperplasia the serum magnesium levels were raised, as was the serum potassium, and there were lowered sodium levels in the untreated condition. Serum levels of these cations were corrected by the administration of mineralocorticoids.

The mechanism by which renal excretion of magnesium is carried out is poorly understood. In primary aldosteronism the mechanism of the hypomagnesaemia is a matter of speculation. Magnesium waste in this condition was ascribed by Mader and Iseri (1955), Miller, Faloon, and Lloyd (1958), and Hills et al. (1959) to an intrinsic tubular defect constituting an additional pathophysiological feature of kaliopenic nephropathy, while Hanna and MacIntyre (1960) considered that hypomagnesaemia was not due to kaliopenic nephropathy, but to the direct affect of alcosterone itself.

The present study of serum electrolytes in $\mathrm{CAH}$ revealed that the serum magnesium level was high before the serum sodium and chloride were corrected; and the administration of mineralocorticoids resulted in drastic lowering of serum magnesium and potassium with the correction of serum sodium. With regard to the relationships of these cations, there was an inverse correlation between serum magnesium and sodium, and serum magnesium showed a direct correlation with serum potassium and an inverse one with serum $\mathrm{Na} / \mathrm{K}$ ratio only when there was hyponatraemia. Based on these findings, the following conclusions were drawn: mineralocorticoids reduced serum magnesium level when serum levels of sodium and chloride were corrected, and the effects of mineralocorticoids on serum magnesium and potassium were similar in mineralocorticoid deficiency in man. Further studies on this problem are thought to be necessary.

\section{Summary}

Serial determinations of serum magnesium and other electrolytes $(\mathrm{Na}, \mathrm{K}$, and $\mathrm{Cl})$ were carried out in two infants with the salt-losing type of congenital adrenal hyperplasia (21-hydroxylase deficiency) treated with salt supplement and combined administration of mineralo- and glucocorticoids. Serum magnesium and potassium levels which were raised in the untreated condition returned to normal after the administration of DOC-trimethylacetate with parallelism. Serum magnesium levels were inversely proportional to serum sodium levels. In the hyponatraemic condition serum magnesium levels showed a direct correlation with serum potassium and an inverse one with serum $\mathrm{Na} / \mathrm{K}$ ratios. It is strongly suggested that mineralocorticoids reduce serum magnesium level when serum sodium and chloride are corrected, and that the effects of mineralocorticoids on serum magnesium and potassium are very similar in mineralocorticoid deficiency in man.

The authors wish to thank Prof. T. Takatsu for his constant interest and guidance in this investigation, and Drs. H. Komiya, S. Takita, H. Murata, H. Kawaguchi, and S. Egi for their assistance in determining serum electrolytes and urinary steroids.

\section{REFERENCES}

Barker, E. S., Elkinton, J. R., and Clark, J. K. (1959). Studies of the renal excretion of magnesium in man. $\mathcal{F}$. clin. Invest., 38, 1733.

Bongiovanni, A. M., and Eberlein, W. R. (1958). Critical analysis of methods for measurement of pregnane-3 $\alpha, 17 \alpha, 20 \alpha$-triol in human urine. Analyt. Chem., 30, 388.

Chesley, L. C., and Tepper, I. (1958). Some effects of magnesium loading upon renal excretion of magnesium and certain other electrolytes. f. clin. Invest., 37, 1362.

Conway, E. J., and Hingerty, D. (1946). The influence of adrenalectomy on muscle constituents. Biochem. $\mathcal{F} ., 40,561$.

DaVanzo, J. P., Crossfield, H. C., and Swingle, W. W. (1958). Effect of various adrenal steroids on plasma magnesium and the electrocardiogram of adrenalectomized dogs. Endocrinology, 63,825 .

Drekter, I. J., Heisler, A., Scism, G. R., Stern, S., Pearson, S., and McGavack, T. H. (19j2). The determination of urinary steroids. I. The preparation of pigment-free extracts and a simplified procedure for the estimation of total 17-ketosteroids. $\mathcal{f}$. clin. Endocr., 12, 55.

Few, J. D. (1961). A method for the analysis of urinary 17-hydroxycorticosteroids. F. Endocr., 22, 31.

Ginn, H. E., Smith, W. O., Hammarsten, J. F., and Snyder, D. (1959). Renal tubular secretion of magnesium in dogs. Proc. Soc. exp. Biol. (N.Y.), 101, 691.

Glenn, E. M., and Nelson, D. H. (1953). Chemical method for the determination of 17-hydroxycorticosteroids and 17-ketosteroids in urine following hydrolysis with $\beta$-glucuronidase. $\mathcal{F}$. clin. Endocr., 13, 911. 
Hanna, S., and MacIntyre, I. (1960). The influence of aldosterone on magnesium metabolism. Lancet, $2,348$.

Harrop, G. A., Soffer, L. J., Ellsworth, R., and Ti escher, J. H. (1933). Studies on the suprarenal cortex. III. Plasma electrolytes and electrolyte excretion during suprarenal insufficiency in the dog. f. exp. Med., 58, 17.

Hills, A. G., Parsons, D. W., Rosenthal, O., and Webster, G. D., Jr. (1955). Observations of magnesium metabolism in man. $f$ clin. Invest., 34, 940.

- - Webster, G. D., Jr., Rosenthal, O., and Conover, H. (1959). Influence of the renal excretion of sodium chloride upon the renal excretion of magnesium and other ions by human subjects. ibid., 19, 1192 .

Hingerty, D. (1957). The role of magnesium in adrenal insufficiency. Biochem. F., 66, 429.

Horton, R., and Biglieri, E. G. (1962). Effect of aldosterone on the metabolism of magnesium. f. clin. Endocr., 22, 1187.

Jabir, F. K., Roberts, S. D., and Womersley, R. A. (1957). Studies on the renal excretion of magnesium. Clin. Sci., 16, 119.

Kobayashi, A. (1967). Neonatal hypomagnesaemia. Lancet, 2, 100.

-, and Shiraki, K. (1967). Serum magnesium level in infants and children with hepatic diseases. Arch. Dis. Childh., 42, 615.
Mader, I. J., and Iseri, L. T. (1955). Spontaneous hypopotassemia, hypomagnesemia, alkalosis and tetany due to hypersecretion of corticosterone-like mineralocorticoid. Amer. F. Med., 19, 976.

Miller, T. R., II, Faloon, W. W., and Lloyd, C. W. (1958). Divergence in magnesium, sodium and potassium excretion during stimulation of endogenous aldosterone production. $f$. clin. Endocr., 18, 1178.

Milne, M. D., Muehrcke, R. C., and Aird, J. (1957). Primary aldosteronism. Quart. F. Med., 26, 317.

Schachter, D. (1961). Fluorometric estimation of magnesium with 8-hydroxy-5-quinolinesulfonate. f. Lab. clin. Med., 58, 495.

Schales, O., and Schales, S. S. (1941). A simple and accurate method for the determination of chloride in biological fluids. f. biol. Chem., 140, 879.

Weil, P., and State, D. (1958). The effect of the removal of major endocrine glands on the serum level of magnesium in dogs. Surg. Gynec. Obstet., 107, 483.

Womersley, R. A. (1956). Studies on the renal excretion of magnesium and other electrolytes. Clin. Sci., 15, 465.

Zwemer, R. L., and Sullivan, R. C. (1934). Blood chemistry of adrenal insufficiency in cats. Endocrinology, 18, 97. 